\title{
処方薬乱用者のゲートキーパーとしての薬剤師 :「まちの科学者」を取り戻す
}

\author{
嶋根卓也
}

\section{The Pharmacist as Gatekeeper of Prescription Drug Abuse: Return to "Community Scientists"}

\author{
Takuya Shimane \\ Department of Drug Dependence Research, National Institute of Mental Health, National Center of \\ Neurology and Psychiatry; 4-1-1 Ogawa-Higashi, Kodaira, Tokyo 187-8553, Japan.
}

(Received August 10, 2015)

\begin{abstract}
The non-medical use or abuse of prescription drugs, including benzodiazepines, is a growing health problem in Japan. An association between prescription drug overdose and suicide risk has also been reported. The Japanese Ministry of Health, Labour and Welfare has expected pharmacists to act as "gatekeepers", facilitating early identification of individuals at high risk of prescription drug abuse including overdose, supplying medication counseling to patients, and helping to introduce these patients to appropriate medical care. Prescription drugs such as benzodiazepines are widely used in psychiatry. However, these drugs are prescribed not only by psychiatrists but also by other healthcare professionals including primary care physicians. Moreover, in recent years, the dispensing of prescriptions has moved rapidly from inside to outside hospitals, with prescription drugs being dispensed mainly at community pharmacies. Although all healthcare professionals including hospital pharmacists can play a role in preventing prescription drug abuse, the role of the community pharmacist is vital in addressing this problem. Formerly, community pharmacists were recognized as “community scientists", low-threshold accessible healthcare advisors. Now, community pharmacists should return to the role of community scientists to prevent prescription drug abuse. This article begins by reviewing the current situation of prescription drug abuse and dependence in Japan. The role of pharmacists as gatekeepers in preventing prescription drug abuse is then examined. Finally, this article discusses the effect of intervention in the form of gatekeeper training for community pharmacists.
\end{abstract}

Key words_ - prescription drug abuse; overdose; suicide prevention; gatekeeper; pharmacist

\section{1.はじめに}

処方薬乱用の拡大一それは医薬品の適正使用を推 進してきた薬剤師にとって，看過できない問題と言 える，特に，ベンゾジアゼピン系薬剤 [以降，benzodiazepine（BZ）薬と表記）を中心とする睡眠薬 や抗不安薬を乱用し, 薬物依存となる患者は, 確実 に増加傾向にある．また， BZ 薬を含む処方薬乱用 は，過量服薬（いわゆる，オーバードーズ）を引き 起こす要因にもなる，さらに過量服薬は，自殺の背 景となる可能性も指摘されている，処方薬乱用は， 命に係わる事態にまで発展する危険性のある問題な

国立研究開発法人国立精神・神経医療研究セン夕ー精 神保健研究所薬物依存研究部（T187-8553 東京都小平 市小川東町 4-1-1)

e-mail: shimane@ncnp.go.jp

本総説は, 日本薬学会第 135 年会シンポジウムS52 で 発表した内容を中心に記述したものである.
のである。

処方薬乱用には, 睡眠薬や抗不安薬などの多剂大 量処方が生み出した「医原病」という側面があるこ とは否定できない。つまり，乱用や依存のリスクを 考慮せず，安易に多剂大量処方を繰り返してきた医 療側にも責任があるということだ。言うまでもな く，わが国において処方権は医師にある。薬剤師が 多剤大量処方や患者の処方薬乱用に気づき, 減薬あ るいは処方内容の変更が必要と判断しても, 現行の 医療システム下では, 薬剂師からの働きかけだけで 処方を適正化することは困難という声も耳にする. では，処方薬乱用が医原病であるとして，薬剤師は 何ができるだろうか. 乱用を続ける患者に対して, 漫然と処方を続ける医師に対して，薬剤師は何をす ることもできないのだろうか.

本稿では, 処方薬乱用を薬物依存及び過量服薬の 視点から捉え，まずはその実態について論じる，そ 


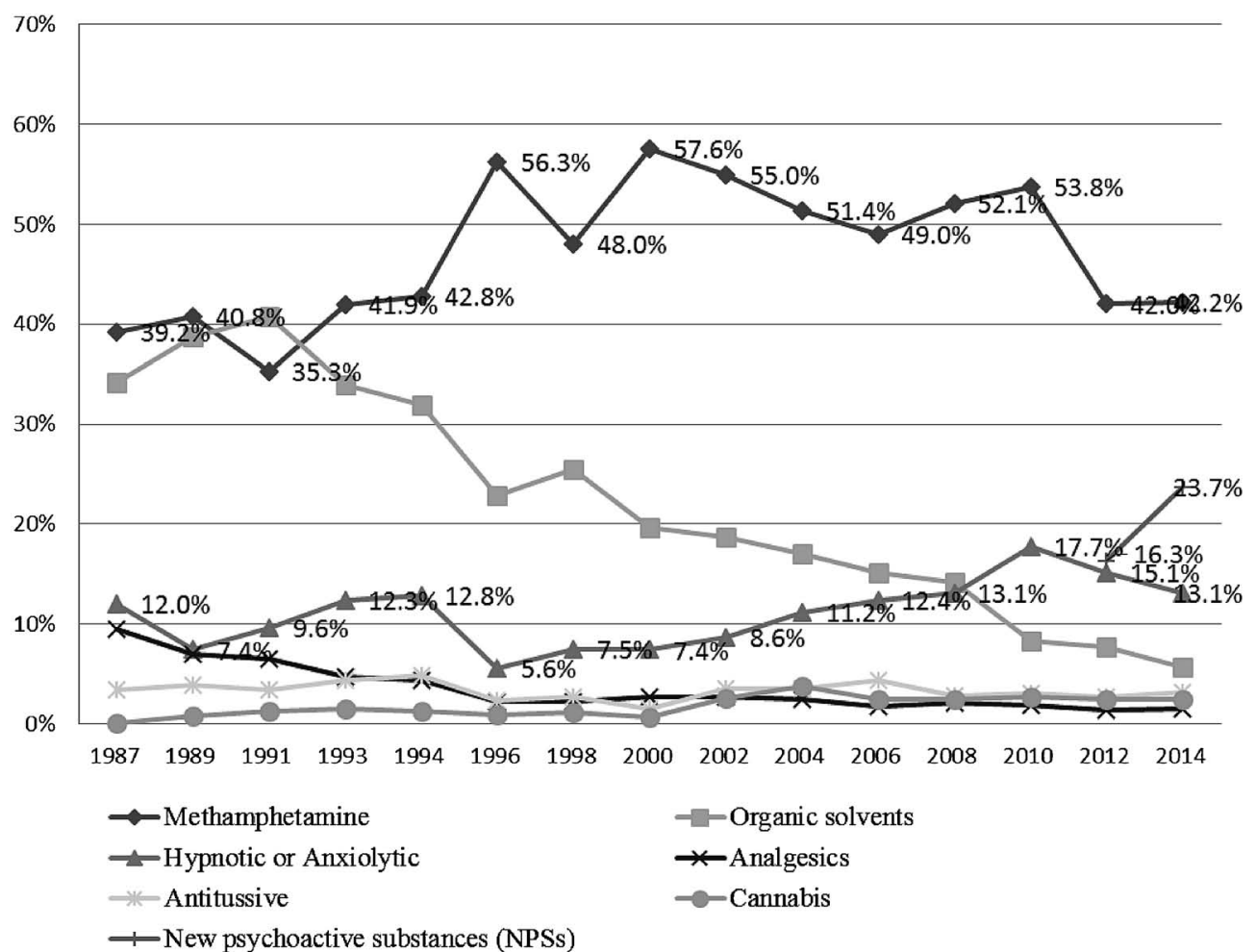

Fig. 1. Percentage of Patients with Specific Substance Use Disorders in Mental Hospitals in Japan (1987-2014)

Adapted from Matsumoto T., Takano A., Tanibuchi Y., Tachimori H., Wada K. Research Report, Health and Labour Sciences Research Grant "Research on the Regulatory Science of Pharmaceuticals and Medical Devices"' (H25-iyaku-ippan-018), Ministry of Health, Labour and Welfare, 2015, pp. 95-128.

して，過量服薬や自殺対策として注目されている ゲートキーパーに焦点をあて, 薬椷師が処方薬乱用 者のゲートキーパーとして期待される背景や果たす べき役割について論じる。さらに，薬剤師向けの ゲートキーパー研修のプログラムやその効果につい ても論じていきたい.

\section{2. 処方薬乱用の実態}

2-1. わが国における処方薬乱用の現状 わが 国における処方薬乱用の中心的課題は，睡眠薬や抗 不安薬の乱用である。2014 年に実施された全国の 精神科医療施設調查 ${ }^{1)}$ によれば，睡眠薬や抗不安薬 （主として BZ 薬）を入院の主たる原因物質とする 薬物依存患者は，覚せい剂症例，危険ドラッグ症例 についで多い患者群となっている（Fig. 1).

薬物依存患者のうち, 睡眠薬や抗不安薬の依存患 者が占める割合は，17.7\%（2010 年）， $15.1 \%$ (2012 年), $13.1 \%$ （2014 年）と一見減少している ように見える。しかし，これは危険ドラッグ乱用が 2011 年前後に爆発的に流行し，危険ドラッグ症例 が占める割合が増えたことにより, 睡眠薬や抗不安 薬の依存患者が占める割合が相対的に圧縮された結
果である. 実際, 症例数でみれば，119名(2010 年), 128 名（2012 年）, 207 名（2014 年）と年々増加し ている (Fig. 2).

2-2. 睡眠薬 · 抗不安薬症例の臨床的特徵 松 本らは，2010 年に実施された全国精神科医療施設 調査で得られたデー夕を基に, 覚せい剤症例との比 較により, 睡眠薬・抗不安薬症例の臨床的特徵を報 告している. ${ }^{2)}$ なお, 同研究では, 睡眠薬・抗不安 薬をまとめて「鎮静剤」と表記している。鎮静剤症 例は覚せい剂症例に比べて，女性の比率が高く，年 齢が若年であり, 反社会的行動のエピソード（暴力 団や非行グループとのつながり，逮捕・補導歴な ぞ）が低率という特徵がある.

Figure 3 に示したように，鎮静剤症例は，乱用開 始の動機が覚せい剤症例と大きく異なる点にも注意 が必要である，鎮静剤症例の乱用動機は，「不眠の 軽減」,「不安の軽減」,「抑うつ気分の軽減」のよう に，苦痛の緩和を目的としている，つまり，乱用の 背景には，睡眠障害や気分障害といった原疾患を抱 えている可能性が高く, 自身が抱える不快症状に対 し, 処方薬乱用という不適切な方法で自己治療的に 


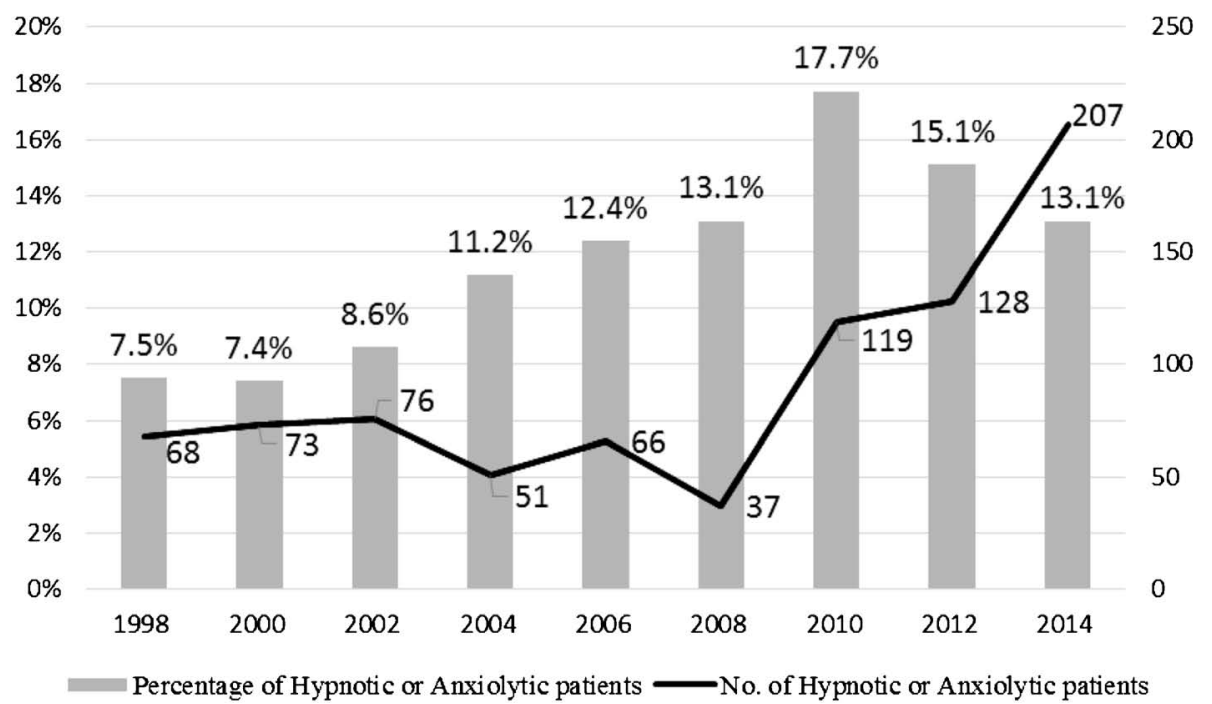

Fig. 2. Percentage and Number of Patients with Hypnotic- or Anxiolytic-related Disorders

Adapted from Matsumoto T., Takano A., Tanibuchi Y., Tachimori H., Wada K. Research Report, Health and Labour Sciences Research Grant "Research on the Regulatory Science of Pharmaceuticals and Medical Devices" (H25-iyaku-ippan-018), Ministry of Health, Labour and Welfare, 2015, pp. 95-128.

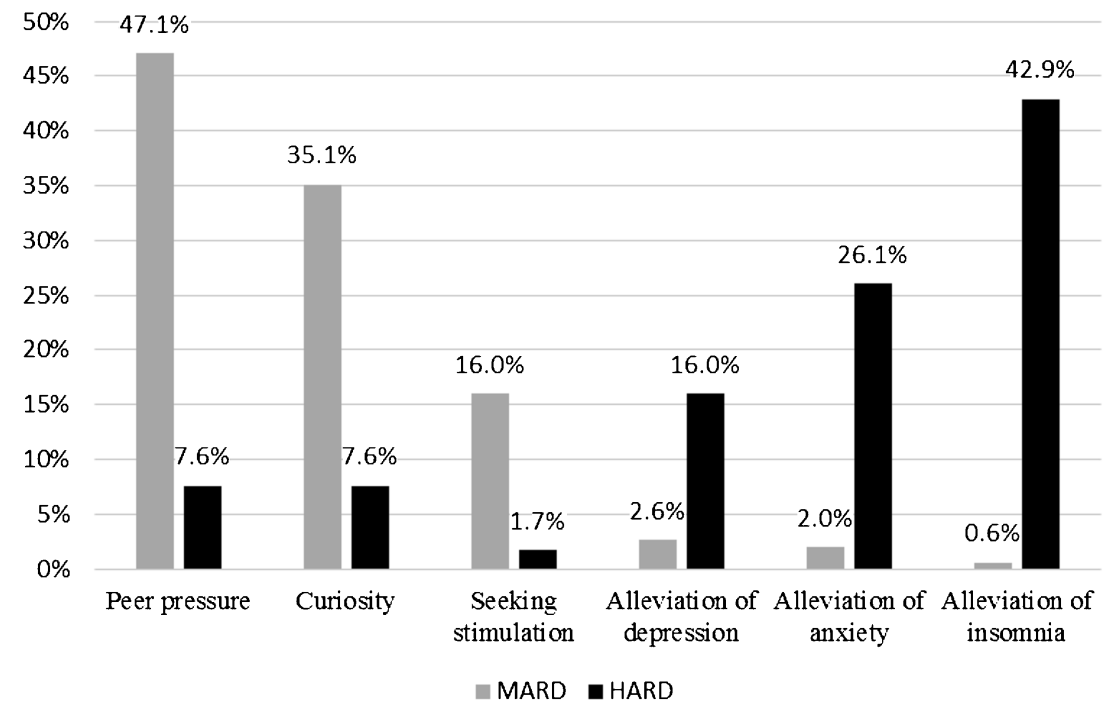

Fig. 3. Reason for Drug Abuse in the MARD and HARD Groups

MARD: Methamphetamine-related disorder patients, HARD: Sedative- (hypnotic or anxiolytic) related disorder patients. Adapted from Matsumoto T., Ozaki S., Kobayashi O., Wada K. Seishin Shinkeigaku Zasshi, 113, 1184-1198 (2011).

対処している臨床像が想像できる.

一方，覚せい鼡症例では，「誘われて」，「好奇心 から」，「刺激を求めて」のように，仲間からの誘い や刺激希求が乱用開始の背景にある。なお，危険ド ラッグ症例の乱用動機は，覚せい剂症例と類似して (る. ${ }^{3)}$

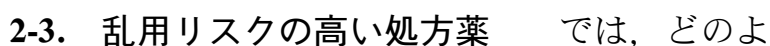
うな薬剤が乱用の対象となっているのか．前述の全 国精神科医療施設調査 ${ }^{1)}$ によれば，症例数が最も多 い薬剤として etizolam（120 症例）が挙げられ， flunitrazepam (101 症例), triazolam (95 症例), zolpidem（53 症例）と続いている。この 4 剂に関 しては，調剤報酬明細書（レセプト）を情報源とし た重複処方の実態調査 ${ }^{4)}$ とも共通しており, etizolam は重複処方においても最も多い薬剤であった (Table 1).

このように etizolam が, 乱用リスクあるいは重 複リスクの高い薬剤となっている理由は，やはり向 精神薬としての指定がないため，長期処方になり易 いことが背景にあると考えられる。また，etizolam 
Table 1. Number of Abusing and Overlapping Patients by Specific Psychotropic Drug

\begin{tabular}{cccc}
\hline \hline $\begin{array}{c}\text { Psychotropic } \\
\text { drug }\end{array}$ & $\begin{array}{c}\text { Schedule } \\
\text { I-III }\end{array}$ & $\begin{array}{c}\text { Patients } \\
\text { abusing } \\
(n)\end{array}$ & $\begin{array}{c}\text { Patients } \\
\text { overlapping } \\
(n)\end{array}$ \\
\hline etizolam & not regulated & 120 & 46 \\
flunitrazepam & Schedule II & 101 & 5 \\
triazolam & Schedule III & 95 & 11 \\
zolpidem & Schedule III & 53 & 23 \\
Vegetamin $^{\circledR}$ & Schedule III & 48 & - \\
nitrazepam & Schedule III & 35 & 2 \\
brotizolam & Schedule III & 32 & 21 \\
nimetazepam & Schedule III & 32 & - \\
alprazolam & Schedule III & 27 & 6 \\
bromazepam & Schedule III & 18 & - \\
zopiclone & not regulated & 12 & 7 \\
diazepam & Schedule III & 11 & 5 \\
estazolam & Schedule III & 11 & 3 \\
\hline
\end{tabular}

a Adapted from Matsumoto T., Takano A., Tanibuchi Y., Tachimori H., Wada K. Research Report, Health and Labour Sciences Research Grant "Research on Regulatory Science of Pharmaceuticals and Medical Devices" (H25-iyaku-ippan-018), Ministry of Health, Labour and Wel-

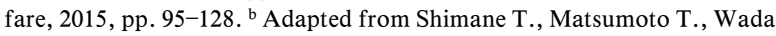
K., Jpn. J. Alcohol \& Drug Dependence, 47, 202-210 (2012) .

の適用症は幅広く, 睡眠障害を始め, 頚椎症・腰痛 症・筋収縮性頭痛における不安・緊張・抑うつ及び 筋緊張を取り除く目的でも使われる。このため, 精 神科や心療内科のみならず，内科，整形外科など幅 広い診療科で処方されることも重複処方の一因かも しれない.

2-4. 過量服薬と自殺とのつながり 処方薬乱 用が引き起こす問題は, 薬物依存の増加に留らな い. 処方薬乱用を続ける患者の中には, 手元に大量 の処方薬を貯めこんでいる事例が少なくない．貯め こまれた処方薬は, 過量服薬（いわゆるオーバー ドーズ）を引き起こす原因となる。薬物依存症専門 医療機関 4 施設を対象とした調査によれば，BZ 薬 乱用者の $51.7 \%$ が「過量服薬による救急医療機関 への搬送」を経験していることが報告されている. ${ }^{5)}$ 一方，救急外来における過量服薬患者の $77.7 \%$ が $\mathrm{BZ}$ 薬を過量服薬していたことも報告されている. ${ }^{6}$

そして，過量服薬の問題は，自殺リスクを高める 可能性がある. 自殺既遂者の遺族を対象とした心理 学的剖検調査によれば，生前に精神科受診歴を有す る自殺者の約 $60 \%$ が，自殺行動におよぶ直前に， 手元にある処方薬を過量服薬していたことが報告さ れている. ${ }^{7)} \mathrm{BZ}$ 薬等の過量服薬によって惹起された 酩酊状態，あるいは脱抑制効果が，衝動性が高く,
Table 2. Motives Chosen by Self-poisoners to Explain Their Episodes of Deliberate Self-harm

\begin{tabular}{lc}
\hline \hline & $\begin{array}{c}\text { Self-poisoners } \\
(n=86) \\
n(\%)\end{array}$ \\
\hline I wanted to get relief from a terrible state of mind. & $53(72.6)$ \\
I wanted to die. & $50(66.7)$ \\
Show how desperate I was feeling. & $29(43.9)$ \\
I wanted to find out if someone really loved me. & $28(41.2)$ \\
I wanted to punish myself. & $25(38.5)$ \\
I wanted to get some attention. & $19(28.8)$ \\
I wanted to frighten somenone. & $16(24.6)$ \\
I wanted to get my own back on someone. & $11(17.2)$ \\
\hline
\end{tabular}

Adapted from Rodham K., Hawton K., Evans E., J Am Acad Child Adolesc Psychiatry, 43, 80-87 (2004).

致死的な行動を促進した可能性が指摘されている. このように処方薬乱用は, 命に係わる事態にまで発 展する危険性がある。治療目的で処方された薬剤 が，言わば「自殺を後押しする道具」として使われ ている現実は, 医薬品の適正使用を推進する立場で ある薬剤師には無視できない事態であろう.

2-5. 過量服薬者の動機過量服薬と自殺との つながりが指摘されているものの, 即座に過量服薬 を自殺行動と判断すべきではない，Rodham らによ れば，過量服薬エピソードを持つ青少年の動機とし ては「辛い感情から解放されたかった」という理由 が最も多く，「死にたかつた」という理由を上回つ ていることが報告されている（Table 2)。年このよ うに, 過量服薬の背景には, 苦痛を緩和させたいと いう目的があり，これはリストカットなどの自傷行 為とも共通する心理である，その他，「自分が絶望 している様を見せたかった」や「自分が本当に愛さ れているのかを確かめたかった」という動機から過 量服薬をする若者もいる。こうした動機を踏まえる と, 過量服薬という自らの身体を傷つける行動は, 死ぬためではなく，自身が抱えている様々な「生き づらさ」への対処行動あるいは，周囲に発したメッ セージと捉えることができるかもしれない.

過量服薬が「生きづらさ」への対処行動であると して，自殺リスクと無縁かと言えば決してそのよう なことはない. Owens らは, 青少年期に過量服薬 エピソードを持つ者を 16 年間追跡し, 過量服薬を 経験した若者のその後の自殺率は高く, 過量服薬の 対象として精神安定剤や抗うつ薬を使用していた場 合や，意識障害が重症であった場合は，自殺リスク 


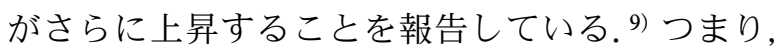
過量服薬に気づいた援助者は，気づいた時点で，で きることから介入しないと，取り返しがつかない事 態にも発展する可能性があることを示唆する知見と 言えよう。

2-6. 医原病としての処方薬乱用 処方薬乱用 には, 睡眠薬や抗不安薬などの多剂大量処方が生み 出した「医原病」という側面があることは否定でき ない。「薬剤を貯めている可能性を顧慮せずに漫然 と処方を続けることが，処方薬依存の発症に影響し たと考えられる一般精神科における最大の問題点」 という指摘もあるくらいだ. ${ }^{5)}$ そこで，平成 26 年度 診療報酬改定では，多剤大量処方を適正化するため の見直しが行われた．例外規定はあるが，1 回の処 方において，3 種類以上の睡眠薬・抗不安薬，4 種 類以上の抗うつ薬・抗精神病薬を投与した場合, 精 神科継続外来支援・指導料は算定できず，処方せん 料・処方料・薬剤料については減算されることに なった。

\section{3. 処方薬乱用のゲートキーパーとしての薬剤師}

3-1. ゲートキーパーとは 自殺は「追い込ま れた末の死」と形容される。なぜなら，自殺者の多 くが健康問題, 経済問題, 家庭問題などを背景に, 心に悩夕を抱えており，目の前にある辛い状況を打 破するためには「死ぬしかない」と追い込まれるよ うに自死を選択する事例が後を絶たないからであ る. 自殺者数はここ数年で減少に転じているとはい え，平成 26 年版自殺対策白書によれば，年間 2 万 7 千人以上が自らの命を断つ事態が続いている.

ゲートキーパーとは，わが国の自殺対策で提唱さ れている概念である．ゲートキーパーが担う主な役 割は，「悩んでいる人に気づき，声をかけ，話を聞 いて，必要な支援につなげ，見守ること」であり， 言わば「命のサポーター」とも言える存在である. 医療関係者のみならず，保健，福祉，教育，行政， 地域のボランティアなど，様々な立場の人たちが ゲートキーパーの役割を担うことが期待されている.

厚生労働省の自殺・うつ病等対策プロジェクト チームは，過量服薬対策をまとめた「過量服薬への 取組一薬物治療のみに頼らない診療体制の構築に向 けてー」の中で，向精神薬を服用する患者との面会 機会が多い薬剤師は，過量服薬のリスクの高い患者 のゲートキーパーとなり得ることを明記している.
また，平成 24 年に見直された自殺総合対策大綱に おいても，「調剤や医薬品販売を通じて住民の健康 情報に接する機会の多い薬剤師をゲートキーパーと して養成する」と明記された。

処方薬乱用の早期発見・早期介入は，まさに薬剤 師とゲートキーパーがつながる接点と言える。その 他，自殺の危険因子として知られている精神障害， アルコールの有害使用，慢性疼痛など，日常臨床に おいて薬剤師が患者の異変に気づける機会は多い.

ゲートキーパーとしての薬剂師が担う具体的な役 割は，「気づき」，「係わり」，「つなぎ」に分けて整 理することができる. ${ }^{10)}$ 薬剤師は，服薬指導の場面 において, 服薬状況や患者の様子から, 患者の異変 に気がつくことがある（気づき）。その際は，患者 に声をかけ，患者の話を傾聴し，悩みを抱えた患者 に寄り添うことが求められる（係わり）。さらに, 必要な支援に患者をつないでいくことが求められる 役割である（つなぎ）。病気や症状に関することで あれば，主治医との連携が不可欠であり，患者の同 意を取得した上で，患者情報をフィードバックする ことが必要となる。しかし，処方薬乱用の背景に は，家族関係，職場ストレスや失業，ひきこもり， いじめ, 介護疲れ，虐待や育児不安，多重債務など の経済問題など様々な社会的問題や，「生きづらさ」 が存在していることもあり, 必要に応じて, 保健 所・精神保健福祉センター・福祉事務所等の行政機 関につないでいくことも検討する.

3-2. 薬剤師の関与が期待される理由薬剤師 がゲートキーパーとして期待される第一の理由は, 薬剤師は向精神薬などの処方薬を服用する患者との 面会機会が多いことにある．近年では院外処方率が 上昇しており，平成 26 年社会医療診療行為別調查 によれば，院外処方率は病院で 75.4\%，診療所で $70.6 \%$ と報告されている。つまり，BZ 薬を含む処 方薬の多くが, 地域の薬局で調剤され, 薬剤師から 患者に手渡していることになる。このため地域の保 険薬局に勤務する薬剤師が果たすべき役割は特に大 きいと言える。したがって，薬剤師が乱用リスクの 高い薬剤を服用している患者に応対する際には，薬 物依存や過量服薬の可能性を考えながら服薬指導を することが必要である．実際，薬剂師が患者の過量 服薬や自殺リスクに気がつくことは少なくない.

Shimane らによれば，薬局薬剂師の $26 \%$ ，過去 1 
年以内に過量服薬患者と対応した経験があると報告 されている. ${ }^{11)}$ また，Kodaka らによれば，精神科 専門薬剂師の $58 \%$ が自殺未遂者との対応を経験し たことがあると報告されている. ${ }^{12)}$

第二の理由は，薬剤師は患者の服薬状況から処方 薬乱用のリスクに気づき易い立場にいるからであ る. 入院患者に対する病棟での服薬指導から, 通院 患者に対する院外処方まで，患者の服薬管理を行う ことは薬剤師の役割である。処方薬乱用者の中に は，複数の医療機関を重複受診している事例や，自 宅に大量の薬剤を貯めこんでいる事例も散見される ことから，服薬指導の場面において併用薬，他科受 診，残薬などを薬剤師が確認することは，処方薬乱 用の早期発見につながると考えられる。 また，前述 した乱用機会の高い薬剤 (etizolam 等) が処方され ている患者に対しては，依存性に関する服薬指導を 適切に行うことも期待される。なお， BZ 薬乱用患 者のうち，処方薬の依存性に関する説明を受けてい た者はわずか $32.9 \%$ という報告もある. 5 )

第三の理由は，薬剤師は患者にとつて身近な相談 相手になり得るからである. 薬局薬剤師を対象とし た調査によれば,「医師への相談はためらうものの, 薬剂師に対しては希死念慮(死にたいと願う気持ち) や，過量服薬の事実を相談する患者」がいることが 報告されている.13) これは，医師に対する遠慮ある いは，処方薬乱用という不都合な事実を隠したがる 気持ちが影響している可能性がある。それに対し て，薬剤師は患者にとってより身近な医療従事者と して相談できるのかもしれない.

第四の理由は，全国に薬局が膨大にあるというこ とである. 乱用の対象となる処方薬は，精神科のみ ならず，様々な診療科で処方機会がある，処方薬乱 用は単独の医療機関，単独の医療者だけで防ぐには 限界がある。したがって一人でも多くの医療者が ゲートキーパーの役割を担い，処方薬乱用に早期に 気づき，適切な対応をとる必要がある。全国には, コンビニエンスストアの数 (49323 カ所, 平成 25 年コンビニエンスストア統計調査年間集計）を上回 る薬局数（57071 力所，平成 25 年度衛生行政報告 例）があることを踏まえれば，地域の薬剤師はゲー トキーパーに適した職種と言えよう。薬局に勤務す る薬剤師一人ひとりが処方薬の適正使用を推進する ことで，処方薬の過量服薬や薬物依存を早期に予防
できる可能性がある.

\section{4. 薬剤師向けゲートキーパー研修}

4-1. プログラムの概要 処方薬乱用や自殺リ スクのある患者のゲートキーパーとして期待される 一方で，薬剤師の多くは薬物依存や自殺リスクの高 い患者に対する支援に関して，十分な知識や技術を 持っているとは言えない。従来，薬剤師と患者のコ ミュニケーションは，「服薬」に関する限定的なも のであり，患者のメンタルヘルス支援に特化したも のではなかったからである.

そこで，近年では自殺・過量服薬対策の一環とし て，最低限の知識や技術を身につけるためのゲート キーパー研修会が各地で開催されるようになった。 筆者は，日本薬剂師会地域保健委員活動の一環とし て，処方薬乱用防止に重点を置いた研修プログラム を作成し，埼玉県薬剂師会及び兵庫県薬剤師会をモ デル地区として研修を実施した。

研修プログラムは，計 7 時間（1 日間）であり， 講義編とグループワーク編から構成される．講義編 では，処方薬乱用を取り巻く現状や，過量服薬と自 殺とのつながりに関する基礎知識を習得した。 さら に，リスクの高い患者との服薬指導で注意すべき事 項（傾聴，希死念慮の確認，処方医との情報共有な ど）など具体的な応対方法について学習した。ま た，医療機関以外のネットワーク先として，メンタ ルヘルスの専門的な相談に応じることができる精神 保健福祉センターや，処方薬依存を含む薬物依存症 の支援を行っている民間施設である Drug Addiction Rehabilitation Center (DARC) の職員を招聘 し，その活動を理解する機会を設けた.

グループワーク編では, 1 グループ 8 名程度の小 グループに分けて，実践的なグループワークを行っ た. 自殺リスクの高い患者のサイン（気づき）や, 地域の相談支援資源（つなぎ）については，グルー プ内で意見を出し合い，付箋を用いて模造紙に貼り， $\mathrm{KJ}$ 法の要領でカテゴリーに分類した。なお，この ワークでは自治体が発行している相談先一覧を活用 しながら地域の各種相談空口を学んだ。また，リス クの高い患者との服薬指導に関しては, 事例に基づ き，ロールプレイング形式で患者とのコミュニケー ションを学習した.

4-2. プログラムの効果 プログラムの効果測 定は, 厚生労働科学研究費補助金医薬品・医療機器 
等レギュラトリーサイエンス政策研究事業の一環と して行われた. ${ }^{14)}$ 前述の研修を実施した埼玉県薬剤 師会の薬剂師を対象に，プログラムの効果を測定し た。研修を受講した介入群 83 名に対しては，介入 2 力月前, 介入直前, 介入直後, 介入 6 力月後の 4 時点で，受講しなかった対照群 231 名に対しては, 介入 2 力月前, 介入 6 力月後の 2 時点において自記 式質問紙調査を実施した。

介入群では，介入直前から介入直後にかけて処方 薬乱用者やゲートキーパーに関連する知識や態度 （自己効力感）が大幅に上昇し，その上昇は，介入 6 力月後まで維持されていた。一方，対照群では大 きな変化はみられていない。研修プログラムに受講 することで，ゲートキーパーの役割を担う上での知 識や態度が改善され，その効果が半年後まで維持さ れていることが示唆される.

研修プログラム参加者の自由記載によれば，「向 精神薬や精神病薬の服薬指導に対して，及び腰だっ た参加前に比べ，つなげることができる安心感か ら，積極的に一歩踏み込んだ指導ができるように なつた」，「傾聴いつも心がけています，元気をも らったと言って頂くことも増えました」，「話を聞い てあげると安心した様子で，私たちも嬉しい」のよ うに，患者との服薬指導が質的に変化している様子 も窥われる。

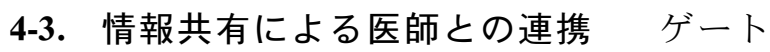
キーパー研修の効果は, 知識や態度の変化のみなら ず，薬剤師の臨床行動にも現れている点にも注目し たい. Figure 4 に示したように，介入群では，研修 プログラム受講の前後で，過量服薬者に関する情報 を処方医にフィードバックする割合が有意に上昇し ている（T1 介入前 $53.8 \%, \mathrm{~T} 4$ 介入後 $73.1 \%$ ）。前 述のように，過量服薬等の事実を主治医には話さ ず，薬剤師に告白する患者も存在することから，薬 剂師が知り合えた患者の様子を主治医にフィード バックすることは，ゲートキーパーとして担うべき 役割の 1 つと言える.

診察時に語られなかつた過量服薬者の情報を薬剂 師から処方医へ提供することで，再乱用防止に向け た注意喚起となる可能性や，処方が過量服薬に配慮 した内容（処方量，処方日数，使用薬剤）に見直さ れる可能性が高い。例えば，東京女子医大病院で は，精神科と薬剂師との協働啓発活動により，BZ

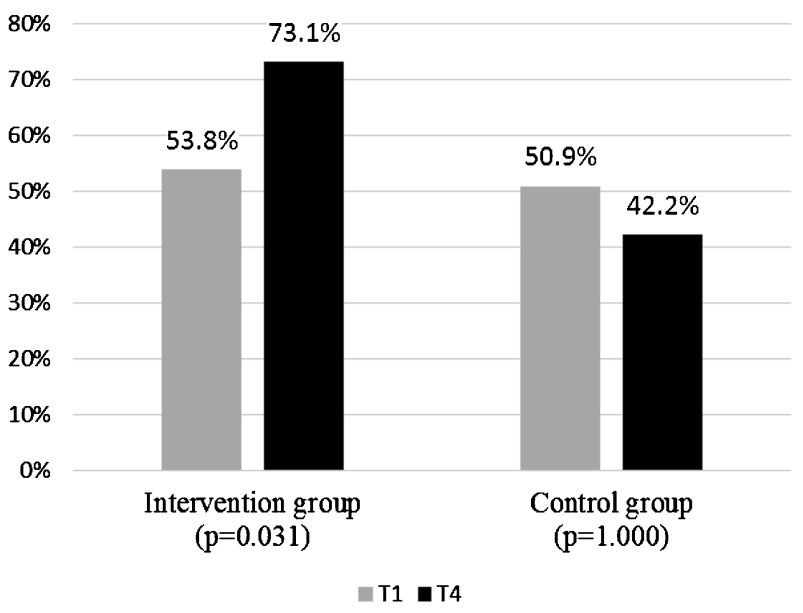

Fig. 4. Percentage of Pharmacists Who Reported or Provided Feedback about Prescription Drug Abuse to the Prescriber between $\mathrm{T} 1$ to $\mathrm{T} 4$

$p$-value for McNemar test (paired), T1: Before intervention (clinical behavior in past six months), T4: After intervention (clinical behavior in past six months). Adapted from Shimane T., Fujiwara H., Miyano H., Nishikawa S. Research Report, Health and Labour Sciences Research Grant "Research on Regulatory Science of Pharmaceuticals and Medical Devices" (H25-iyaku-ippan-018), Ministry of Health, Labour and Welfare, 2015, pp. 169-179.

薬の処方患者数を低下させた実績が報告15)されてい ることから，薬剤師から医師への働きかけにより， BZ 薬などの処方を適正化していくことは十分に可 能と考えられる。

なお，所属機関が異なる薬局と病院（あるいは診 療所）との情報共有は，言うまでもなく患者の同意 取得を前提とする．患者から同意をスムーズに得る ためには，患者との信頼関係を日頃から構築してい くことが不可欠である。ただし，個人情報保護法に は，本人の同意を得ることが困難である場合であっ ても，「人の生命，身体又は財産の保護のために必 要がある場合」などの例外が明記されているため, 薬物乱用の蓋然性が極めて高く，それによる周囲の 人間への危険や不利益が十分に予見されると判断さ れた場合には，医療関係者との連携・情報共有は妥 当適切なものとみなされる可能性が高いという指摘 もある. ${ }^{16)}$

一方，残された課題もある. 医師とコメディカル スタッフ（薬剂師を含む）との情報共有は，精神病 院等では日常的に行われる行為であるが，地域の薬 局と医師とのコミュニケーションは，かならずしも スムーズとは言えない. Shimane らによれば，医師 とのコミュニケーションに自信がない薬剤師や，医 師とのトラブルを避けたいと考えている薬凨師は, 
Table 3. Multivariate Indicators of Pharmacists' Self-evaluation of Referral to the Prescriber

\begin{tabular}{|c|c|c|c|c|}
\hline & \multicolumn{4}{|c|}{ Self-evaluation of referral to the prescriber } \\
\hline & \multirow{2}{*}{$\begin{array}{c}\begin{array}{c}\text { Good } \\
(n=195)\end{array} \\
n(\%)\end{array}$} & \multirow{2}{*}{$\begin{array}{c}\begin{array}{c}\text { Poor } \\
(n=158)\end{array} \\
n(\%)\end{array}$} & \multirow{2}{*}{$\begin{array}{c}\text { Adjusted } \\
\text { OR } \\
(95 \% \mathrm{CI})\end{array}$} & \multirow{2}{*}{$\underset{\text { value }}{p}$} \\
\hline & & & & \\
\hline \multicolumn{5}{|l|}{ Perception of the inhibition factor for referral to the prescriber (agree) } \\
\hline Insufficient knowledge about addiction & $31(15.9)$ & $23(14.6)$ & $0.9(0.5-1.7)$ & 0.717 \\
\hline Insufficient confidence in communicating with prescriber & $18(9.2)$ & $30(19.0)$ & $2.7(1.4-5.3)$ & 0.003 \\
\hline Busy work schedule & $24(12.3)$ & $20(12.7)$ & $1.0(0.5-2.0)$ & 0.905 \\
\hline Don't want to help prescription drug abuser & $4(2.1)$ & $2(1.3)$ & $0.7(0.1-4.2)$ & 0.699 \\
\hline To avoid trouble with prescriber (trouble between individuals) & $50(25.6)$ & $55(34.8)$ & $1.7(1.0-2.7)$ & 0.041 \\
\hline To avoid trouble with hospitals or clinics (trouble between institutions) & $46(23.6)$ & $28(17.7)$ & $0.8(0.4-1.4)$ & 0.371 \\
\hline To avoid trouble with patients and their families & $56(28.7)$ & $64(40.5)$ & $2.0(1.2-3.3)$ & 0.005 \\
\hline
\end{tabular}

Multivariate logistic regression analysis conducted with all variables. CI: confidence interval; OR: odds ratio. Adapted from Shimane T., Matsumoto T., Wada K., Psychiatry Clin. Neurosci, 69, 220-227 (2015) .

処方医への情報提供が「不良」となるリスクが，約 2-3 倍高くなることが報告されている (Table 3). ${ }^{11)}$ また，医師とのやり取りを通じて苦い経験を持つ薬 凰師は少なくない. 多剤大量処方に対して, 繰り返 し処方変更の提案をしても「前回通りの処方なの で，このままで問題ない」と取り合わない医師や， 薬剂師からの疑義照会を極端に嫌がる医師, 電話口 で一方的に激昂する医師もいることも報告されてい る. ${ }^{13)}$ 処方薬乱用を早期発見・早期介入するために も，医師は薬剤師からの情報提供や疑義照会の意義 を正しく理解し, 薬剤師を貴重な情報源として認識 していくことが求められる.

\section{5. おわりに}

今，薬局のあり方が問われている．医薬分業が進 んだとはいえ，いわゆる「門前薬局」の増加により， 薬局は院外処方箋という「入場券」がなければ，立 ち入ることができないような特殊な場所に変わって しまった，処方薬乱用者の中には，目的の薬剤を入 手するために複数の医療機関を受診する多重受診者 も少なくない。こうした患者は，それぞれの「門前 薬局」で薬剤を受け取ることになるため，処方薬乱 用の早期発見を困難にする要因となる，処方薬を交 付する薬局を個人毎に固定する制度や，調剤情報を 一元的に管理するシステムがあれば，処方薬乱用を 防ぐために役立つと考えられる。しかし，言うまで もなく, 薬局の選択は個人の自由であり, 法的な拘 束力はない.

厚生労働省は, 処方薬を受け取る薬局や薬の相談 をする薬局を一元化する「かかりつけ薬局」を推進
しており，一定の基準を満たす薬局を「健康サポー 卜薬局」として認定する制度を検討している. かつ て地域の薬局は，「まちの科学者」と呼ばれ，専門 知識を持つた薬剤師は地域住民から信頼され，尊敬 される存在であったという。地域の薬剤師は, 薬に 関する相談のみならず，薬品や生活に関する幅広い 相談にも応じてきた. 従来, 薬局とは地域に根ざし た存在であったはずである。薬剤師が心に悩みを抱 えた患者に気づき, 患者の話を傾聴し, 適切な支援 につないでいくというゲートキーパーの役割は，本 来の「かかりつけ薬局」が備えていたはずの機能で はなかろうか。薬霅師が処方薬乱用者のゲートキー パーになるということは,「まちの科学者」という 薬剤師としての原点を取り戻す作業に似ているのか もしれない.

謝辞本研究の一部は, 厚生労働科学研究費補 助金 (医薬品・医療機器等レギュラトリーサイエン ス政策研究事業）「脱法ドラッグ」を含む薬物乱用・ 依存状況の実態把握と薬物依存症者の「回復」とそ の家族に対する支援に関する研究（研究代表者：和 田 清) の助成を受けて実施されたものである.

利益相反＼cjkstart開示すべき利益相反はない.

\section{REFERENCES}

1) Matsumoto T., Takano A., Tanibuchi Y., Tachimori H., Wada K., Research Report, Health and Labour Sciences Research Grant 
named Research on Regulatory Science of Pharmaceuticals and Medical Devices (H25iyaku-ippan-018), Ministry of Health, Labour and Welfare, 2015, pp. 95-128.

2) Matsumoto T., Ozaki S., Kobayashi O., Wada K., Seishin Shinkeigaku Zasshi, 113, 11841198 (2011).

3) Matsumoto T., Tachimori H., Tanibuchi Y., Takano A., Wada K., Psychiatry Clin. Neurosci., 68, 374-382 (2014).

4) Shimane T., Matsumoto T., Wada K., Jpn. J. Alcohol \& Drug Dependence, 47, 202-210 (2012).

5) Matsumoto T., Naruse N., Umeno M, Aoyama K., Kobayashi O., Shimane T., Morita N., Wada K., Jpn. J. Alcohol \& Drug Dependence, 47, 317-330 (2012).

6) Ookura R., Mino K., Ogata M., Journal of Japanese Association for Acute Medicine, 19, 901-913 (2008).

7) Hirokawa S., Matsumoto T., Katsumata Y., Kitani M., Akazawa M., Takahashi Y., Kawakami N., Watanabe N., Hirayama M., Kameyama A., Takeshima T., Psychiatry Clin. Neurosci., 66, 292-302 (2012) .

8) Rodham K., Hawton K., Evans E., J. Am.
Acad. Child Adolesc. Psychiatry, 43, 80-87 (2004).

9) Owens D., Wood C., Greenwood D. C., Hughes T., Dennis M., Br. J. Psychiatry, 187, 470-475 (2005).

10) Shimane T., Yakugaku Zasshi, 133, 617-630 (2013).

11) Shimane T., Matsumoto T., Wada K., Psychiatry Clin. Neurosci., 69, 220-227 (2015) .

12) Kodaka M., Inagaki M., Yamada M., Crisis, 34, 420-427 (2013).

13) Shimane T., Jpn. J. Psychiatr. Treat., 87, 8793 (2012).

14) Shimane T., Fujiwara H., Miyano H., Nishikawa S., Research Report, Health and Labour Sciences Research Grant named Research on Regulatory Science of Pharmaceuticals and Medical Devices (H25-iyakuippan-018), Ministry of Health, Labour and Welfare, 2015, pp. 169-179.

15) Takahashi Y., Inada K., Takahashi M., Kimura T., Ishigooka J., Jpn. J. Gen. Hosp. Psychiatry, 27, 27-35 (2015).

16) Kanno N., The Pharmaceuticals Monthly, 56, 1507-1510 (2014). 